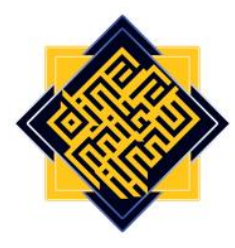

\title{
Scientific Education among Muslims in Northern Nigeria: The Influence of Middle Eastern and Mediterranean Scholarship
}

\author{
Mukhtar Umar Bunza \\ Usmanu Danfodiyo University, Sokoto, Nigeria \\ e-mail:cf398@cornell.edu \\ Lawal Abdulkarim \\ Usmanu Danfodiyo University, Sokoto, Nigeria \\ e-mail:cf398@cornell.edu
}

\section{Abstract}

In the study of Islamic education, the scientific and medical contributions of Muslims globally are incongruously positioned. In most cases, Islamic education is completely divorced from its conventional scientific research and experimentation known and appreciated in its early and classical periods. Science and medicine are not alien in Islamic epistemology, though, have suffered gross neglect in the Muslim World in recent centuries. However, the universality and connectivity among the Muslims in the world since the beginning of the Islamic mission has been one of the gluing and cementing factors in the Muslim world intellectually and culturally, which made spread and diffusion of literature and scholarship across Muslim communities reciprocally. It is thus, not a surprise to find that, not only on the spiritual and educational facets but also in scientific and medical spheres the classical writers of the Middle Eastern and Mediterranean regions got their ways and significantly impacted the Muslim scholars of the nineteenth century northern Nigeria. The paper, therefore, aims at tracing and analyzing the extent of influence of those (Middle Eastern and Mediterranean regions) scientific literatures on the perception, motivation, as well as research, documentation, and experimentation in fields of sciences and medicine in Muslim Northern Nigeria. Special consideration will be given to the works by Sultan Muhammad Bello, d. 1837, who wrote quite a number of treatises on different aspects of sciences, followed by Sheikh Abdullahi Fodiyo d. 1829, and others who followed after them. The research will also explore how in turn, 


\section{Mukhtar Umar Bunza \& Lawal Abdulkarim}

their educational works on scientific and medical research also impacted on the Muslim societies in Nigeria and beyond, especially in the codification and enlistment of the scientific resource materials on the wider educational spheres and the curricular of the Muslim societies of the area, since the last two centuries.

Keywords: Mediterranean World, Middle East, Northern Nigeria, Scientific Education

\section{A. Introduction}

Education in Islam knows no bounds; any useful knowledge that helps in improving and advancing human survival and wherewithal on earth, whether attained through revelation or acquired process, is practically and essentially part and parcel of religion. There is, therefore, no distinction between 'spiritual' and 'conventional' knowledge in Islam. That was the reason why early Muslim scientists were concurrently versatile in religious, natural sciences, and philosophy. Thus, one of the greatest contributions of Islamic civilization in most communities globally is the awakening of literary pursuit and knowledge acquisition. That was due to the fact that the entire rites and practices in the religion revolve round reading, recitation, and liturgy. The first and foremost is to be able to understand and read the Qur'an, Hadith of the Prophet as well as other related literature on law and history of the early period of the religion- Sira. Consequently, there was institutionalization and incorporation of book culture as well the emergence of libraries, reading, and research centers, which had become synonymous with the presence of Islamic influence in the society. That was the history of educational cum scientific advancement in the DamascusSyria, Baghdad-Iraq, Al-Azhar-Egypt, Qairawan-Morocco, Timbuktu, Jenne in -Mali, Katsina, Kano, Borno, as well as Agadez in the present Nigeria and Niger republic respectively. That adorable history of learning and knowledge-oriented societies hugely influenced the Muslims perception and reaction to education generally. The emergence of scholars-ulama, proliferation of literature, marketing, and commoditization of literature (prominence of booksellers, book markets, and job opportunities as copyists and scribes;) were as a result of educational and intellectual encouragement embedded in Islam and symbolized by early Muslim polities and institutions. Further, high esteem and swift change of social status enjoyed by men of letters as highly regarded, rewarded, and merited class of people, with shortcut license to material and political wealth significantly influenced the pattern of education and learning in the Muslim World generally and Northern Nigeria in particular.

The Northern Nigerian case was, however, not an exception for many reasons. Principally, the region was the hub and nucleus of Islamic civilization and educational development in West Africa. Almost all major Islamic centers in North and West Africa emptied their treasures of scholarship into the region (Bunza, 2020). The antique presence of Islam in the area also aided the education and learning culture amongst the people to 
thrive. Islam was introduced in the area around 10th to 11th centuries and developed to a State Religion in the 15th century with examples of Songhai Empire under Askia Muhammad, (1493-1538) and Kano Kingdom under Muhmmad Rumfa, who reigned from 1463-1499.

Most of the literatures and books studied at various stages of learning and knowledge development in Muslim Northern Nigeria since the 15th century were largely Mediterranean and Middle Eastern by origin. The nature of schools ranging from Makaranrun Allo- Slate Schools- mainly for children and beginners as well as Makaratun Ilimi- Schools for higher education-were established based on the Spaniard-Andalusian, Moroccan, Egyptian, Tunisian and Algerian styles (Bunza, 2013).

\section{B. Northern Nigerian Muslims and Quest for Scientific Education of the Mediterranean and Middle Eastern World}

It is worthy of note that the areas referred to today as Northern Nigeria has had developed early contact with the Mediterranean as well as Middle Eastern areas since the pre-Islamic eras. The record of trade and cultural as well as political linkages were recorded since the Greek and Roman periods, with the salt, slaves, hide \& skin, and the gold of West Africa.

The commercial and trade link was further cemented by the introduction of the religion of Islam since the 10th and 11th centuries, correspondingly, the centers of commerce re-emerged as new centers of learning, and itinerant scholars from North Africa and other regions of West Africa trooped and settled in the region in higher numbers, (Bunza, 2012). Consequently, educational and intellectual activities developed, and states adopted the system and started refashioning polities and governance towards Islamic ethics, which made it challenging and imperative to aligning almost all state operations based on Islamic guidelines.

The religion of Islam, in the context of the Qur'an and Sunnah is the full scientific expression, appeals and encouragement for its acquisition. Believers are consistently invited to ponder on the creation of heavens and the earth, alteration of day and nights, rotation of the Sun, Moon Stars, and other mysteries of galaxies in order to scientifically established reasons and proofs beyond doubt about the existence and greatness of God. The creation of mountains to hold the earth not shake, the seas and the oceans as well as the lofty ships that sail on it, the creation and procreation of humans, the formation of rainfall as well the germination of crops are continuously referred to by the Qur'an as signs for people of faith with understanding. As a Muslim society and emerging new capital and seat of Islam in the 19th century West Africa, the Northern Nigerian areas, therefore, should have exemplified the scientific appeal in theory and practice. That may well be as the main motivating factor among others for the quest and thriving of scientific education in the region.

Therefore, new Islamic polities, especially the Sokoto Caliphate, 1804-1903, championed the propagation of new Islamic Systems in the hitherto traditional Hausa state system and relics West African ancient Kingdoms of Ghana, Mali, and Songhay. The new Islamic State of West Africa at Sokoto was faced with the challenge of changing not only 
cultural and juridical apparatus but also educational and medical. Basically, only with clear scientific proofs as encouraged by Islam, that the superstitious beliefs, which often contradict Islam, could be uprooted and replaced. Therefore, reforming the minds and behavior as well as traditional and cultural milieu could be more successful and durable if the emphasis is given to knowledge and scientific finding. To achieve that, the founders of the Sokoto Caliphate invested enormous resources in developing internal mechanisms as well as creating external linkages with scholars and research centers to accomplish the task.

In the same vein, the prevalence of epidemic and other health challenges confronted by the new Islamic polity urged in search for alternative means which mainly could be found in the well-established educational and religious centers that preceded the Sokoto Caliphate for centuries in the Middle East and Mediterranean region, which served as centers of Islam, science, technology, and medicine.

Scientific education is the whole mark of medical practice and its formidable pillar. Thus, removing the medical practices and cure away of the spirits -Iskoki(in Hausa), Jinbased on the existing Bori Cult prevalent in the traditional setting of the society. Islamic system cannot be successful and comprehensive until it dismantled the contours and vicissitudes of spirit veneration, divination, and occult rites in medication and cure. That was the basic principle upon which the Northern Nigeria Muslims since the emergence of the Sokoto Caliphate in 1804, viewed scientific education as a background to faith-oriented and compliant medical exercise and encouraged it pursuit in theory and practice (Bunza, 1995). Above all, scientific education as well as medical research and practices were viewed as means of improving the lots of the people as well as alleviating the suffering of the afflicted and indigents and a gateway to earning the pleasure of Allah by rendering service to His creatures. In the light of the above, not only the Muslim Northern Nigerian areas but as well, most other Muslim societies globally rely on the Middle East and Mediterranean regions for inspiration, resources, structure, and superstructure in order to meaningfully enhanced the scientific and religious education base of its populace.

\section{Mediterranean World and Diffusion of trade and Knowledge into West Africa/ Northern Nigeria}

The importance of Mediterranean and Middle Eastern regions in world civilization and development is unquestionable. Indeed, the regions serve as the hub of human civilization, especially along the Nile in Egypt, Athens in Greece, Constantinople- present-day Istanbul, Turkey, Euphrates, and Tigris as well as the Mesopotamia and Assyrian civilizations in Iraq and Syria had significantly influence developments in most parts of the world; West Africa and Nigeria, not an exception. The Sahara did not pose a barrier between North Africa, the Mediterranean Worlds and West Africa (Boahen, 1964); Gold, salt, spices, hides and skin, ivory as well as slaves were imported in a large scale to the Greece regions, Roman, Egyptian, Spanish, Italian, and French through the other parts of the Mediterranean countries of Africa such as Morocco, Algeria, as well as Egypt Libya and Tunisia. The trade across the Sahara between the North and West Africa was a phenomenon of very remote 
antiquity; that was according to (Keita,1994), 'the contextual basis lies in the fact that African far from being separated from Classical civilization, was in fact, an intrinsic and integral part of it'. These trade routes, therefore, continued to facilitate and connect the two regions of the African continent up to the 2oth century, which opened a window of unprecedented transformation in communication and transportation systems.

The western route came from Morocco through Zemmour and Adrar to the Bank of Senegal and the Niger; then there was the second route running from Tripoli through Ghadames, Ghat, and Hoggar to Gao on the Niger. Through that network, commercial, religious, and cultural contacts were established between the Mediterranean worlds, the Saharan, and beyond (Boahen: 1964). It was further affirmed that:

...caravans from Sudan, including all the large cities, but especially from Kano, from Borno, from Tibboo (Tibu), from Tout, from Fezzan, from Souf, from Ghadames and from Tripoli, Tunis and the north coast, visited the Ghat souk (market) of this interior'. The main routes included Morocco- Taodemi- Timbuktu route, Ghadames- Air- Kano route, Tripoli- Fezzan- Borno route (described as the most ancient, shortest, and most active and well-known route), and Cyrenaica- Kufra-Waday route (Boahen: 1964 \& Hunwick, 1992).

Central Sudan, otherwise known as Northern Nigeria became a very important region to reckon with in the subsequent centuries of trade; and derived most of its culture, belief, and tradition from the outside world, mainly the Middle East, through trade relations. It was based on this premise that Hogben and Kirk-Greene: 1968 explained the nature and character of the peoples of northern Nigeria. They note that:

Today's (Hausaland) northern Nigerians carry the chromosomes of a variety of ancient peoples, including the Berbers, Jewish, and Arab immigrants from the North deriving their civilization and traditions from the Mediterranean regimes of Carthage and Rome, Greece, and Byzantium, as well as from the Islamic empires of Spain, Maghreb, Egypt, Syria, and Mesopotamia. Mixed in varying degrees with these hereditary strains are those of the ancient indigenous people of Sudan, who later absorbed the higher-skinned immigrants from the north and intermarried with them... No serious study of Nigerian history, therefore, can afford to ignore either the main course of events in the Maghreb and around the Mediterranean when contacts with Sudan were beginning to be explored or the strong Arab-Muslim influence which have permeated the whole of Sudan for thousand years. The heights of civilization achieved under the Khalifate in Cordova, Cairo, and Baghdad at a time when parts of Europe were still uncouth and unlettered deserve to be more widely recognized (emphasis added).

Through the trade linkages, the people of Northern Nigeria and the inhabitants of these regions have been closely connected for many centuries. Further, Christopher Rose noted that, the relationship did not only flourished as a result of the North African and Mediterranean connections with the sub-Saharan Africa, but learning and scholarship, science and architecture also thrived, which consequently resulted to the emergence of citadel of learning and universities especially in Timbuktu and Jenne in 15th century and later the Sokoto Caliphate, (Rose 2003). 


\section{Mukhtar Umar Bunza \& Lawal Abdulkarim}

The development of indigenous scholarship since the 16th century in the Muslim Northern Nigeria was a result of the impact of the other parts of the Muslim World. The Mediterranean side of Africa and Europe as well as the intellectual hub of Middle East, especially Syria and Iraq made an indelible imprint on the intellectual patterns of this region.

The result of the intellectual endeavor of these regions directly in proxy could be adjudged by the emergence of indigenous ulama- scholars- who became luminaries and icons of knowledge and education and had at different periods of their lives established renown education centers with sole aim of advancing knowledge and learning. Almost all of them traveled to either Cairo, Algeria, Maghreb, or some centers of learning in Hijaz for more education and establishing contact with other scholars and sources of scholarship. Some of these ulama included:

- Muhammad bin al-Sabbagh (d.1640), popularly known as Dan Marina. Some of his literary contribution as indicated by (Hunwick, 1995) include: Mazjarat al-Futyan ala taf nur Allah bil'l isyan (in verse); Kha'iyyah fi madh amir al-Mumineen Karyagiwa(in verse); Daliya fi Madh Mai Ali and Sharh Ishriniyyat (commentary of Ishriniyyat of Alfa Zazi). In Muzjirat al-fityan copy available electronically at Arewa House Kaduna, alSabbag enlisted the field of knowledge which he ventured and studied. These include figh, tafsir, grammar, syntax, the science of Hadith, ilm al- Huruf, mirath-distribution of inheritance- science of recitation of the holy Qur'an -such as tajweed and others. But for the science of astrology and numerology he suspended and discontinued the study for fear of what it may led to transgression.

- Muhammad bin Masanih (d.1667) al-Barnawee al-Katsinawee popularly known as Dan Masani. Among his books are, Ayn al-Khalas fi Tilawat surat al-lkhlas, Azhar al-ruba fi akhbar Yuruba, Buzugh al Shamsiyyah fi Sharh al-Ishmawiyyat, Fath al-Maram bi-mithl Qasidat Ibn Hisham, Manzuma laisa fiyha harf Manqut, Nazm fi 'add shurrah alMukhtasar; Ta'lif ala ma'rifat ma yaqbal al sarf wa adimahu. The later is on Arabic grammar.

- Muhammad al-Wali bin Sulayman al-Baranwee al-Kabawee(d.1688-9) was of Kebbi origin. Some of his noted works include: al-Adillah al-Ihsan fi bayan tahrim shrub alDukhan, Arsat al-Maram li'l Talib al-Qasid lil'ilam, al-Manhaj al-Farid fi ma'rifat ilm alTauheed, Mu'in al-Talib wa mufid al-Ragib, and Manzuma al-Hafidah.

- Muhammad bin Muhammad al- Fullani al-Katsinawi al-Dan Rankawi, (d.1741) He was described as a scholar highly respected among scholars and students for his knowledge and was held in high esteem by scholars in the Middle East. Aljabarti, according to Kani (1984) described him as the cynosure, the theologian, the ocean of learning, the sea of knowledge, the unparalleled, the garden of science and disciplines, the treasury of secret and mysticism. Kani also enlisted Minah al-Quddus( on logic), Bulugh al-Arab min Kalam al-Arab, and some titles on Sufism and Astrology as part of his literary contribution. Others include, Bahjat al-Afaq wa-idah al-lubs wal-Ighlaq fi ilm al-huruf, Bughyat al-Mawali fi tarjamat Muhammad al-Wali, Rihla, al-Tahrir alRaiqah, etc. 
- Muhammad bin al-Hajj Abd al-Rahman al-Khatib al-Barnawi,(d.1746). Some of his works include: al-Kawkab al-Durri fi nazm ma ja' fi'l Akhdari, Maratib al-Tartib fi Nahy Munkar lada'l Taqrib, Manzuma fi al-Nahw, Sharh al-Ajurumiyyah, Shurb al-Zulal, etc.

As a continuum to that intellectual legacy of the $16^{\text {th }}, 17^{\text {th }}$ and $18^{\text {th }}$ centuries, the $19^{\text {th }}$ century stood as the golden period of Islamic Education in Northern Nigeria. It witnessed an unprecedented surge in knowledge production and reproduction since the introduction of Islam in the region. The major trio contributors to educational and intellectual awakening and development were Shehu Usmanu Danfodiyo, d. 1817, Abdullahi Fodiyo, d. 1829, and Muhammad Bello, d. 1837. Hundreds of literatures in all fields of human endeavors were authored by them, ranging from theology, jurisprudence, law, Qur'an exegesis, language, rhetoric, and grammar, as well mathematics, medicine, earth science, town planning, and land administration. However, they clearly acknowledge and appreciate other scholars in the making of an intellectual revolution that characterized their period and were champions of. The disposition of Mallam Abdullahi on the general importance of knowledge and teaching of the populace as the foundation and bedrock of their movement was confirmed and depicted by Zahradden (1990), as follows, 'Abdullahi considered education as the bedrock for success in all affairs of life'. In the opinion of Abdullahi, 'knowledge to us is the foundation of every work, and nothing is approved that is done in ignorance. Every good comes from following (the Sunnah), and every bad comes from starting (an innovation). Further, from the general highlight of the learning and education process, methodology, and accomplishments of the triumvirates one can vividly establish the connection between the Middle Eastern/ Mediterranean scholarship and the education in the Muslim Northern Nigeria, (see details in Bunza, 2016). In Ida' al-Nusukh fima Akhaztu min al-Shuyukh, Abdullahi accounts their tutors as well some major books they studied in the following:

... among them (who taught us) was the son of our maternal Aunt Muhammad son of Muhammad from whom I learned the Maqamat of al-Hariri and other works... Abdullahi son of Muhammad ibn al-Hajj al-Hassan son of Hamm son of Ali, from whom I learnt of the grammatical works Qatr al-Nada and its commentary by alMaridini, Shudhur al-Dhahab and its commentary Bulugh al-Arab, the Khulasa of Ibn Malik with its commentary al-Bahjat al-Mardiya by al-Suyuti, and other works on grammar...Ibrahim al-Barnawe, from whom I learned of the Arabic works, al-Tuhfat al-Wardiya, al-Khulsa and parts of its commentary Manhajal-Salik of al-Ushmuniy, and other works... Muhammad Sambo from whom I learned Farida of al-Suyuti... Ibrahim al-Mandari from whom I learned al-Durar al-Lawami of al-Tahir, al-Ramiza fi ilm alarud, al-Qawafi, al-Tiryaq fi ilm al-Awfaq, and other works... Muhammad al-Firabri, from whom I learned the science of logic, and Waraqat of Imam al-Haramain on the science of the origin of the law... Shaikh Ahmad ibn Abi Bakr ibn Ghari from whom I learned books on the science of rhetoric such as al-Talkhis, with its commentary, Alfiyat al-Ma'ani with its commentary on the Niqaya of al-Suyuti, and other works... imam al-Hajj Jibril ibn Umar.. rom him I learned books on the origins of the law, such as al-Qarrafi, al-Kaukab al-Sati, and Jam' al-Jawami', and its commentary. He gave us 
Alfiyat al-Sanad which his Shaikh al-Misri Murtada had composed, and had given him license to pass on, together with all that he recited...Shaikh Mahmud al-Zamfari alTawri from whom I learned the science of seven readings, such as the composition in verse of ibn al-Barri, and Qasida of al-Shatibi(Abdullahi Fodiyo, Hiskett, trans, 1968).

The magnitude of the learning process embarked upon by the triumvirate in ensuring the educational and intellectual legacy in the region, the and enormous literature largely coming from different parts of the Muslim World as well number of scholars confirmed the level scientific and scholarly pedigree of Northern Nigeria in the $19^{\text {th }}$ century. Hunwick (1995) accounted for about one hundred and thirty-one (131) books of Shehu, one hundred and eleven (111) books to his brother Abdullah, one hundred and sixty-two (162) books to his son Muhammad Bello and seventy-five (75) (most of them Qasaids- poems- and translations) to his daughter Nana Asma'u.

The level of in-depth research and intellectual sagacity could be established and affirmed in the quality of their writings. In Najm al-Ikhwan (one of pre-1804 books) of Shehu Danfodiyo alone, a number of books were cited and acknowledged in order to justify the position he took on some juristic issues. The book, which is divided into eight chapters, is intended to answer some knotty issues bordering on different aspects of the Shari'ah in each of the chapters. In the book alone we have over thirty books which he gave reference to. Some of them include: al-Dur al-Multaqitah of Shykh Abd al-A'ziz, Yawaqit of Abd al-Wahab al-Sha'arani, al-Madkhal of ibn al-Hajj, al-Muhadarat of Hassan al-Yusee, al-Risalat alQuddus of Muhyi al-Deen Ibn al-Arabi those are references in the introduction of the book on justifying the simplicity of the religion of Islam. In chapter one, one finds books like; Kash al-Gumma an-Jami' al-Ummah of abd al-Wahab Sha'rani, Bahjat al-Nufus of Ibn Abi Jamrah al-Asadi, Sharh al-Kawakib of Abd al-Rahman Suyuti, Sharh al-Tanqih of Oarrafi, al-Ahkam fi tamyiz al-Fatawa wa al-Hukum al-Ladhi alaihi al-Fataya fi Mazhab al-Malik of Oarrafi, alBahr al-Maurud fi al-Mawathiq wa al-U'hud of Abd al-Wahab Sha'arani, Irshad al-Shar Sahih al-Bukhari of Qastalani are some of the sources in answering question regarding the legality or not of following a mazdhab-school of thought by a Muslim. In the third chapter, regarding the end of time and the responsibility of the Muslims in the period, his sources included: Kitab al-Nasa'ih wa al-Wasaya of Abd al-Wahab Sha'arani.

On the tension regarding what his brother Abdullah mentioned in his books Diya'alSultan and Diya' Ul-al-Amr wa al-Mujahidin concerning the legality of the use of political titles such as malik, amir or imam in addressing a Muslim leader. Shehu used sources like, Tarikh al-Kulafa', Risalat al-Muluk ( purposely sent to Sultans of Agades, and Katsina by the author) of Imam Suyuti, Tafsir Baidawi, al-Tabari of Ibn Jarir, Raf'u al-Shukuk an Mafakhir alMuluk of Muhammad Shams al-Deen al-Sakhawi and others to respond to the argument. In the last chapter where Shehu addresses reasons for waging jihad against the Hausa rulers his main basis argument was al-Maghili's answers to Askiya on Sunni Ali titled Ajwibat asilah Askiya and Maghili's Misbah al-Arwah fi al-Usul al-Falah were the main reference materials for their actions against Hausaland. That was indeed a demonstration of an academic 
exercise in the works of Shehu, justifying their reliance and extent of influence of those imported books on their intellectual development and emergence as prolific writers (Shehu Danfodiyo, ND, Najm al-Ikhwan, the section used here was translated by the author from Arabic to English for the purpose of this paper).

The scholars from the Mediterranean side of Africa and Europe- Algeria, Morocco, Tripoli, Cairo on the one hand and Cordova, Granada, as well as southern France and Italy, on the other, had played a very important role in the entrenchment of Islamic scholarshipliterature and scholars- in the West African sub-region generally and northern Nigeria in particular. The intellectual connection of the North African/Mediterranean, therefore, with Hausaland via the Sahara in the spread of Islamic religion and scholarship is indubitable. Hiskett (1984) also affirms the influence of Mediterranean and Middle Eastern scholarship and learning patterns on the Muslims of Northern Nigeria. That, it certainly prompted the growth of a similar system in the west and central Sudan, from the great Sankore teaching mosque in Timbuktu where the organization of the Azhar, was deliberately imitated, down to the innumerable makarantun allo and makarantun ilimi of Hausaland. This extensive educational development in Egypt was accompanied by a corresponding degree of intellectual activity. An enormous volume of Arabic literature in prose and verse, covering every aspect of Islam, sciences and language had been produced in Egypt, Cordova, Morocco, Algeria, Syria, Iraq and other major centers of Islamic Civilization globally. These literatures were freely available to the Muslims of the region, and they studied it eagerly. The cultural, religious, educational, and intellectual connectedness between Muslim West Africa generally and Northern Nigeria in particular with the other parts of the Muslim World, especially the Mediterranean and Middle Eastern regions had been well established and sustained to the present time.

\section{Aspects of Scientific Education among Northern Nigerian Muslims}

The aspects of knowledge and education that first came to and studied among the Muslims of Northern Nigeria, were the knowledge of reciting the Holy Qur'an followed by Fiqh- jurisprudence (from simple observance of daily salats, fasting, marriages, hajj, to inheritance), then lugha-language (including rhetoric, grammar, adab and others) followed by knowledge and learning of tafsir- Qur'an exegesis, and Hadith. Knowledge of natural sciences and medicine in a formal learning process I think is a later development institutionalized by the $19^{\text {th }}$ century Caliphate of Sokoto. However, the two sciences were proportionately studied in the Middle Eastern and Mediterranean world. Seldom, books, or treatises before the $19^{\text {th }}$ century clearly discussed the subject of fundamental scientific or medical discoveries and experimentation and reports. As a general guide to study in this field, Ibn Khaldun in Al-Muqaddimah affirms that:

"It has been said: The students of this science(Alchemy and other related sciences) must first know three things: (1) whether it exists, (2) what brings it into being, and (3) how it comes into being. If the student of alchemy knows these three things well, he achieves his object and knows as much as can be known about this science. "As to the problem of the existence of alchemy and the proofs for the (forces) that bring alchemy 
into existence, the elixir that we have sent to you is a satisfying answer. "The question of what brings alchemy into being implied, according to alchemists, search for the stone that makes the (alchemical) operation possible. Potentially, the operation may be performed with any (conceivable) thing because the (potentiality to perform the operation) comes from the four natures (elements)(Ibn Khaldun, Franz trans, (1978, p.326).

Before the $19^{\text {th }}$ century intellectual revolution, Medical knowledge was not codified in the region. Medical knowledge was not part of the curriculum of studies. The study and practice of medicine were shrouded in a rubric of mysticism and secrecy. Following the Mediterranean and Middle Eastern tradition, therefore, resulted in the transformation in Medical studies in the region fundamentally through documentation and codification of medical texts. According to Connor 1994, the same trend was also observable in North America, where in the late nineteenth century, there was thriving industry to meet the public demand for books on health and domestic medicine'. Medical documentation as a sound tradition of the civilized societies, its wisdom and advantages were again argued by Connor 1995, that:

The written word (better than oral transmission more popular at the time in northern Nigeria) has been central to the transmission of medical knowledge in the West, from manuscript copying of ancient corpuses to the modern tradition of textbook publishing. In Eastern medicine too, medical texts have been edited, compiled, and republished continuously over the past 2,500 years: in a union of history and literature, the Chinese Institute for the History of Medicine and Medical Literature still engages in textual and historical research to edit, annotate, and reprint ancient Chinese medical books.

In the same vein public quest as well as government clear medical and health program to provide for the mass demands made the writing of medical treatises in Muslim northern Nigeria in the $19^{\text {th }}$ century a new phenomenon as worthwhile venture as exemplified by the Classical writers of the Muslim World at the time. The establishment of the Sokoto Caliphate in 1804 opened a new chapter in the study of medicine in Hausaland, which in turn adopted that tradition from the earlier Muslim Caliphates, especially the Umayyad and Abbasid periods. These two periods, according to Dunlop 1971, were the periods when the Muslims conquered and incorporated other civilizations in to the folds of the Muslim world. The areas of Palestine, Syria, Iraq, Egypt, and Persia all homes of ancient cultures prompted the rapid development and growth of science and medicine amongst Muslim primarily due to openness, and accommodation of other's thoughts, knowledge, and civilization.

The Sokoto Caliphate, 1804-1903 considered and adopted these earlier Muslim Caliphate as role models, especially in its attitude and response to scientific knowledge and enquiry; and as such significantly influenced by them. For instance, Abdullahi Fodiyo, d. 1829 argued that, in his opinion, a Muslim should not consult a non-Muslim physician when afflicted by any disease. Doing so tantamount to the highest confidentiality and trust to a non-Muslim, which should have been to a Muslim only. In his response to his uncle's assertion, Muhammad Bello, d. 1837, objected to this 
opinion. In his view, the Sokoto Caliphate must not forbid a practice that was observed in the early Muslim Caliphates- Umayyad and Abbasid precisely. Thus, pointing to the fact that, some amongst the Muslim Caliphs employed the services of non-Muslims physicians and even appointed them as their special advisers on Health, therefore on their own part, that tradition and practice should be observed (see Bunza 1995, citing Abdullahi's Masalih al-Insan and Tib al-Nabawi of Sultan Muhammad Bello on the debate).

To buttress the position of Sultan Muhammad Bello on the matter, the views of Dunlop, (1971), that Mua'wiya the first Umayyad Caliph (661-680), employed physician Ibn Uthal, a Christian of Damascus, Taydhuq- a Greek- served al-Hajjaj, governor of Iraq in the same capacity, and the private physician of Umar ibn Abdulaziz was Abdulmalik b. Abjar al-Kinani who was also head of Alexandria medical school, will be more pertinent and substantiable. In the opinion of Abdulhaleem, (2016), the continues spread of Islam and its civilization as championed by the early Muslim Caliphate made Islam synonymous with the study of science and medicine in most parts of the Muslim world. The northern Nigerian, therefore, is not an exception in this regard. That was, according to him, acknowledged by the Western writers as noted in the following:

With the spread of Islam in the seventh century, a great revival of the sciences took place in the Islami8c world; knowledge of medicine flourished and acquired a truly scientific spirit, and doctors were highly esteemed. As stated by Douglas Guthrie, the progress in medical knowledge during the Islamic era was motivated and inspired by Divine Revelation. In the documentation for that statement, Guthrie cited the translation of an authentic Prophetic tradition, saying: "O servant of God, use medicine because God has not created a pain without a remedy for it'. He stated that Islamic medicine was stimulated by the concepts of faith. Learning and practicing medicine is an act of worship. Wisdom is highly appreciated and always sought-for.

The influence and impact of the Middle East and the Mediterranean region in the initial and formulating medical conception and opinions in the Muslim northern Nigeria could be traced. According to Tarajim al-Akhbar, as cited by Kani (1986), al-Katsinawi owed his success in mastering ulum al-Huruf and al-Awqaf and the sciences of the calendar (al-Mawaqit) in the genre of Maghribean (Egyptian) system of calculation and ulum al-Asrar according to Harfi and Waqfi methods. The book titled; al-Durr al-Manzum wa Khulasat al-Sirr al-Makhtum was described by al-Jabarti as a voluminous work consisting of a Muqaddimah (introduction), five sections, and a conclusion. The book is said to have been completed by the author in Cairo in 1646 .

Scientific education in the field of knowledge of the Stars- Ilm al-Nujum was debated on its legality or otherwise among scholars. The majority hold the opinion that as long the knowledge does not lead to divination and future telling and seeking to know about unseenghaib, it is permissible. Ibn Farid(2021) based his argument on the opinion of those who legalize the system and further reveals some of the major works in the area that impacted on that aspect of education in Northern Nigeria. According to him:

Among the leading texts composed by Muslims on the 'ilm'n-nujuum' (the science of the stars) were: the al-Baari 'Fee Ahkaam'n-Nujuum of Ali ibn Abu'rRihaal as-Shaybaani; the at-Tabsira Fee 'Ilm 'n-Nujuum of Umar ibn al-Madhfar 
Yusef; the al-Madhkhal Fee 'Ilm'n-Nujuum of Abu'l-Abass Ahmad ibn Muhammad as-Sarkhisi; the Masaa'il 'I-Qasraani of Abu Yusef Ya 'qub ibn Ali alQasraani; the Kitaab Tasteeh as-Suwar wa Tabteeh 'I-Kuwar of Abu'r-Rayhan Muhammad ibn Ahmad al-Biruni; the Ajaa 'ib'l-Makhluuqaat of Zakariyya ibn Muhammad al-Oazwini and many others. Among the texts which were widely used by the Fudiawa, the school of the SHEHU, was the famous poem called Qaseedat Fee'l-Buruuj wa'l-Manaazil of Shaykh Husayn ibn Ahmad ibn Ali alHashimi al-Baghdadi; the al-Jawhara Fee Dhamm 'Ilm 'n-Nujuum of Shaykh Hamadaan ibn Ahmad as well as the above-mentioned Hausa poem of Shaykh Abdullahi Dan Fodio called Faati Buurji Ghaghida (Elucidating All the Constellations and Their Mansions). Among the works which severely censored the unrestricted usage of the science of astronomy and especially astrology was the Tanbeeh Ahl'l-Fuhuum 'Ala Wujuub ljtinaab Ahl as-Sha 'adhaba wa'n-Nujuum of Muhammad Bello ibn Shehu ( Ibin Farid, 2021).

Ibn Sina, according to Ibn Farid (2021), designated the 'tabaa'i 'iy' (natural constituents) as the combined constituents which make up the harmony of the material world. The basic elements of material existence are four: fire (naar), air (hawaa), water (maa') and earth (turaab). These four elements are the components of the 'tabaa'i 'iy' (natural constituents) which make up the whole of material existence. The balance and harmony of these elements in creatures is what enables health and physical wellbeing. That idea of balance and natural elements of Ibn Sina and Ibn Khaldun clearly influenced Sheikh Abdullahi Fodiyo in his Masalih al-Insan al-Mutaalliq bil Adyan wa al-Abdaan, to provide a whole chapter on ilm al-Tabi'ah, with which he provided the harmony between the three major elements(hot, cold, air, and earth) as the foundation for environmental and body health (see discussion on this below under disease causation). Further, understanding the knowledge is sine-qou-non, to the understanding of the boy systems and basics for medical and scientific education. That was further confirmed by Ibn Fareed in relation to the works of Abdulkadir ibn al-Mustafa, popularly known as Dantafa, viz:

Shaykh Dan Tafa, thus, asserted that the preservation of the harmony and balance among the 'tabaa'i 'iy' (natural constituents) is that "... which is the assistant to medicine by the prevailing judgment." preserving the balance between the four natural temperaments (tabee 'at arba' ${ }^{\prime}$ ): hot (haraara), cold (baruuda), dry (yabuusa) and wet (ratuuba); and ...to sustaining the harmony between the four humors (akhlaat arba 'a): the yellow bile (safra), the red bile (damm) or blood, the white bile (balgham) which comprises the mucous and phlegmatic fluids, and the black bile (sawdaa); are the fundamental principles underlying the science of medicine(Ibn Farid, 2021).

By preserving the soundness and balance of these four elements, four temperaments, and four humors, psychic and physiognomic well-being is protected in the human being. 
Adversely, with the corruption and imbalance of these, it leads to physiognomic and psychic illness (Ibn Farid, 2021).

\section{E. Aspects of Medical Education among Muslims in Northern Nigeria 1. Why Medical Education}

In human societies former and later hardly find any one rejecting the usage of medical education to improve the condition of health of a person or group of persons; however, the way and manner through which the knowledge is acquired may be contested. In Islam from the onset, knowledge of medicine since the Prophetic period and the Companions its value and position are clearly presented. Imam Shafi'l made it abundantly clear in statement that, 'Knowledge in Islam is twofold: Knowledge of fiqh-jurisprudence for understanding the rites of the religion and the second component is knowledge of medicine for the cure and preservation of the body and health', (cited in Ibn Qayyim, 1994, trans).

In Musugul- Lijain, Sultan Muhammad Bello says, "only under healthy atmosphere or condition of the body some cardinal principles of Islam like prayers and fasting can be performed properly". Therefore, knowledge of preservation of health, is by implication adding to the knowledge of worship of God. He added that whosoever, studies medicine and practiced it, has helped himself, his family, and Muslim community at large and will attract great reward from God. Further, in his Kitab al-Rahmati fi Attib wa al-Hikmah, Bello, in the introduction, stated that "I wrote this book in order to please God. He again, in the same section, cited the saying of Ibn Al-Hajj in his Madkhal that, 'the study and practice of medicine had reached the position of Fard Ain, or specific obligation, due to the neglect of subject by the majority of Muslims. And their dependence on either pagan system of healing or the systems of the Jews and Christians, (see Bunza 1995, citing Muhammad Bello). Therefore, Mohammad Bello write on medicine specifically to help Islamic medicine to establish itself in Northern Nigeria, and West Africa, as no preceding established medical education system flourished in the region. According to Bello then, the propagation of Islamic medicine was a means to a much nobler and more grandiose and... the establishment of the perfect society in Islam (Ismail, 1981).

Similarly, in some cases, medical works and researches are produced as a result of complaints and request from members of society. One identifiable case was the case of Emir of Zazzau who wrote complaints of ailments to Sultan Muhmmad Bello, which was diagnosed as kidney problem by Bello on the analysis of the symptoms. Thus, Kitab Amrad al-Kilyah wa llajiha was written and sent; after the application of the prescriptions, the Emir was confirmed to have cured of the ailment completely. The use of experimentation was another method. Generally scientific and medical education is the product of consistent experimentation, trials and investigation. That was contained in Kitab al-Rahmati where in over one hundred pages, all the contents are reports of laboratory and clinical findings. That was the reason why at the end of every entry, Bello concludes by saying Mujarrab al-Sahih, examined, tested, and found efficacious (see Bunza 1995). As indicated and argued by this paper, in conduct of research as well as experimentation and other facets of scientific and medical education the traces and imprint of the Middle Eastern and Mediterranean worlds 
continue to be appreciated. The same also was observable in titles of works, drugs, and other forms of medical inquiries.

\section{On Titles of Literature}

One of the commonest means of acknowledging the impact of one scholar or literature on another scholar or a geographical entity was citation and acknowledging them as authority worthy of reference in undertaking research in a similar area. In that regard the names of classical Muslim scientists and physicians such as Ibn Sina, Al-Razee, ibn Baytar, ibn Rushd and several others were the main authority and backbone for medical research and development among the Muslim scholars of northern Nigeria. Similarly, most of the literature and treatises compiled and authored by those scholars adopted some titles which are originally from the works the classical Muslim scientists. For instance, Muhammad Bello, d. 1837 wrote a book, which serves as a compendium of his medical researches and experimentations, and indeed an exemplary proof for his medical breakthrough. Bello named the book Kitab al-Rahmati fi al-tibb wa al-Hikmah knowingly fully well the existence of some books of similar titles. Some examples are, of Yemeni scholar and classical scientist Mahdi ibn Ali ibn Ibrahim as-Sabiri al-Yemeni's 'ar-Rahma Fee 'al--Tibb wa'l-Hikma of; and the Kanz'l- 'Uluum wa 'd-Durr'l-Mandhuum Fee Haqaa'iq 'Ilm as-Shari'a wa Daqaa'iq 'Ilm'tTabee' $a$ of spiritual master Muhammad ibn Muhammad ibn Ahmad ibn Turmart alAndalusi(Ibn Fareed, 2021).

"Rahmati" Mercy, and "Hikmah" Wisdom- are two words that dominates discourses on medicine and scientific research in the Muslim world since the time Umayyad and Abbasid dynasties. There was the establishment of Bait al-Hikmah as a pioneer center for Islamic medical and scientific investigation; so, Sultan of Sokoto Muhammad Bello was conscious of that hence the title of his book.

Similarly, one of the oldest Arabic components of medicine, called Firdaus-al- Hikmah (the Paradise of Wisdom) was compiled by Al-Tabari. Another valuable treatise on surgery and small- pox and measles was produced by Al-Razi (Rhazes). The Royal Book on Medicine (Al-Kitab Al-Malik) and the famous Ibn Sina, produced his legendary medical encyclopedia (Qanoon Fi Attib) in 20 volumes, and Kitab Al-shifa book of healing could also be said to have informed Bello's book titled Kitab al-Shifa al-Asqam-book on healing of diseases.

Although there are Islamic medical books entitled Attib-Annabawi, the famous among them is Ibn Qayyim's collection of prophetic medicine, Attib al-Nabawi, as well as Attib alNabawi of Imam Suyuti, Muhammad Bello deliberately titled one of his books on prophetic medicine with same title: Attib al- Nabawi. That further confirmed the influence and impact of these literatures on his medical scholarship. Knowing full well the folly of plagiarism in Islam he maintained a different methodology and style from the previous texts. In the AttibAnnabawi of ibn Qyyim at the introductory part of the book the author discusses on diseases, their types and classification in the Quran and Hadith. On the other hand, that of Bello, started by showing the importance of medicine in Islam and the need for medical practices in Islamic community by the Muslim themselves. In addition, Ibn Qayyim divided 
his books into chapters based on diseases, while Bello did not arrange his chapters on the bases of treatment of diseases. However, these and other similar books on the subject are well cited and documented in Bello's work; at least that serves as parameter in gauging the influence of these literature on him.

\section{Concept of Disease and Cure}

As far as healing and cure of ailments are concerned, Bello's view is straight forward an Islamic stand. However, the influence of the Mediterranean as well as Middle Eastern scholarship and literature are traceable in his works. Sultan Bello considered that, no disease on earth is incurable, because both disease and the cure come from Allah. Therefore, it is part of medicine, he maintained to fill the heart of patient with hope of overcoming his/ her problem. Thus, in the introductions of his medical writings he used to open or start with statements like "praises be to Allah who sends no disease without providing cure for it, the one without whose permission and will no healing or cure takes place." However, in reference to some normal causes Bello mentions in Qaulul Manthur fi adwiyat illat al-bathur, (treatise on piles disease), he mentioned excess feeding to be cause of liver problem, the same as Ibn Khaldun in al-Muqaddimah and Ibn Qayyim in Attib al-Nabawi shows excess feeding as the cause of fever, constipation, and indigestion. Similarly, in Masalih al-Insan almuatalliq bil adyan wa al-abdan, shows that, 'if components that constituted human body do not balance, the body is likely to be sick, if cold supersedes the heat of the body or vice versa the function of the body may be disrupted, thus illness occurs. He treated this in a separate chapter he called Ilmul Tabi'ah or natural science. Abdullahi Fodiyo, ND, further shows in Masalih al-Insan that:

I divided the book into five chapters, chapter one treats IIm Al-Tabiah, (Natural science) and the signs (of Allah) endowed in nature. Chapter two treats Tabiu' al-Agziyah (nature of nourishment). Chapter three discusses about some ways for the preservation of health, chapter four shows how to cure some diseases affecting body limbs, and five gives a general treatment on various body ailments.

The arrangement of chapters and the content of issues discussed are in line with the nature, structure, and arrangements of the classical works of the Muslim physicians, such as Qanoon fi al-Tibb, of Ibn Sina, al-Mughni fi al-Adwiya al-mufrada of Ibn Baytar, as well as alTaahdiya of Ibrahim bin Muhammad al-Demashqee, and several others. Thus, confirming the relationship and influence of the former on the later.

In Diya' al-Ummah fi Adillat al- A'immah as cited in Bunza, (2016) Abdullahi Fodiyo explains the fundamental causes of sickness as follows:

As a general principle regarding heath care Abdullahi discourages over feeding and eating another food before the first one is digested. He further recommends light eating habit, (i.e. avoidance of overfeeding), avoidance of eating one type of food i.e. lack of balanced diet for the preservation of good health. Similarly, he strongly recommends use of fruits and milk as part of diet 
for the safeguarding ones well-being: the same emphasized routine body exercise and sexual satisfaction for a complete physical and mental fitness. For treatment of poisons from scorpion and snake bites, he recommends use of salt and water in treatment. He concludes with verdict on the prohibition of use of wine and other impure and unlawful substances in medication. Finally, he explains that it is not allowed for one to enter a town or place with epidemic outbreak and prohibits the use of magic, divination, and charms (Bunza, 2016, p. 103).

This position is earlier maintained by Ibn Khaldun in his Al-Muqaddimah as indicated earlier. Similarly, in discussing medical ethics, as well as the rules governing patient-nurse- doctor relationship as well as qualities of a good medical personnel are discussed among others in Masalih al-Insan. Abdullahi Fodiyo analyses in Masalih alInsan some fundamental issues in medical sciences such as the relationship between the environment, health, and wellbeing (as presented in Bunza 2016), thus:

...environment is one of the greatest determinant factors in the conservation and improvement of one's health. Temperatures and climate which is the major feature of the environment have a very strong connection with the state of one's health. Therefore, the body should not be exposed to the extremes of the weather (heat or cold), failure to do this causes imbalance in the body functions, which ultimately causes illness. In the same vein, ethics of medical practice for both doctors and nurses are discussed in detail in Masalih, such as confidentiality and avoidance of spread the secrets of the patients on such issues of privacy that only the medical personnel should know. Further, the use laboratory analysis of urine and other specimen for diagnosing and determining of diseases among patients is recommended by Mallam Abdullahi(Bunza, 2016, p.102.) .

\section{On Drugs}

On the prescription, as well as the nature of drugs recommended for treatment of illnesses; especially in the diagnosis and treatment of eye diseases more any other field of medicine, the reliance of the northern Nigerian scholars on the Middle Eastern and Mediterranean literature more visible. Ibn Sina and al-Raze are frequently cited by Bello in Kitab Adwiyat lil-Uyun, Kitab al-Tibb al-Muhini, and Musgh al-Lijain written between 1817 and 1830.

Prescription of lotus, indigo, Hanzal, Habbat al-Saudai, etc for medication, which is mostly materials and herbs of mainly Middle Eastern and Mediterranean societies, are frequently made in most of the medicinal literature of northern Nigeria. The availability of Greek literature of science such as Euclid's works on geometry was also available in the region. In 1824 Clapperton visited Sultan Muhammad Bello at his palace in Sokoto and found him reading the Greek works on geometry. This also suggests the availability of Greek works 
on medicine and related fields among the scholars and literary communities of northern Nigeria since the $19^{\text {th }}$ century.

\section{F. Conclusion}

The paper tried to examine and assess the influence of the Middle Eastern and Mediterranean regions on the study, codification, development, and spread of scientific and medical education among the Muslims in Northern Nigerian areas, especially in the nineteenth century. The study also confirms that, through the comparative study of the available literature from the two regions, some sorts of similarities and connections could be established. Thus, the paper concludes that the impact of Middle Eastern and Mediterranean regions on the general intellectual, scientific and medical spheres of nineteenth century northern Nigeria is indubitable.

\section{BIBLIOGRAPHY}

Abdel-Halem, R. E. (2016). The Spirit of Scientific Enquiry in the Early Islamic World. The International Congress on History of Medicine in Muslim Heritage, FAZ, Morocco.

Bello, O. (1994). Education in $18^{\text {th }}$ Century Nigeria: Tarikh Mustafa al-Torodi. Islamic Academy.

Boahen, A.A. (1964). Britain, the Sahara and Western Sudan, 1788-1861. Clarendon Press.

Bunza, M.U. (1995). The Contribution of Sultan Muhammad Bello to the Development of Medical Sciences in $19^{\text {th }}$ Century Hausaland, M.A. History UDU Sokoto

Bunza, M.U. (2005). The North African Factor in Tajdeed Tradition in Hausaland, Northern Nigeria. The Journal of North African Studies, 10(3), Taylor \& Francis

Bunza, M.U. (2009). An Overview of Medicinal Arabic Manuscripts of the Sokoto Caliphate, in El-Miskin, T., et al. (eds.), Nigeria's Intellectual Heritage: Preserving Nigeria's Scholarly and Literary Traditions and Arabic/Ajami Manuscript Heritage, Nigeria Arabic Manuscript Project, pp.36-51.

Bunza, M. U. (2010). Arabic Manuscripts as Alternative Sources in the Re-Construction of Northern Nigerian History, Jumare I.M., and Y.Y. Ibrahim, (eds.), Arabic Manuscripts and Ajami Potentials for the Development of New Knowledge, Arewa House Kaduna, and Ford Foundation.

Bunza, M.U. (2012). Arabic Medicinal Manuscripts of Northern Nigeria: A Descriptive List. Annual Review of Islam in Africa, University of Cape Town, issue no. 11, pp. 92-96

Bunza, M. U. (2013). The Maghrebian Scholarship and the Development of Muslim Intelligentsias in Sub-Saharan Africa: A Case Study of the Central Bilad al-Sudan, History Research, USA, May, 3, No. 5, pp. 342-352

Bunza, M. U. (2015). Islamic Education in Nigeria: A Brief History of Stability and Transformation, Scholars World - IRMJCR, India, III, Issue I, January, pp. 38-46.

Bunza, M. U. (2016). Gwandu Emirate: The Domain of Malam Abdullahi Fodiyo since 1805, GEDA: Amal Press, Kaduna 
Bunza M. U. (2019). Arabic Manuscripts Tradition as Civilizational Assets for Africa: A Glimpse for Contemporary Exploration into some Nigerian Manuscript Treasures, in Viera Pawliková-Vilhanová in collaboration with Martina Bucková (eds) AD FONTES Reflections on Sources of Africa's Pasts, their Preservation, Publication and/or Digitisation, Bratislava, Slovak Academic Press, pp. 45-8o.

Bunza, M. U. (2020). Islamic Education from North to West Africa, in Toyin Falola \& Jamaine Abidogun (eds), The Palgrave Handbook of African Education and Indigenous Knowledge, Palgrave Macmillan Publishers, 2020, pp. 25-35

Connor, J. J. (1995). Book Culture and Medicine, Canadian Bulletin of Medical History, CBMH/BCHM, 12: pp. 199-209.

Dunlop, D. M. (1971). Arab Civilization to AD 1500, Longman, Libraire du Liban

Fafunwa, A.B. (1977). History of Education in Nigeria, George Allen and Unwin.

Hogben, S.J. \& Kirki-Greene, A.H.M. (1966). The Emirates of Northern Nigeria; A Preliminary Survey of their Historical Traditions. London: OUP,

Hiskett, M. (1984). The Development of Islam in West Africa, Longman.

Hunwick, J. O. (1992). Black Slaves in the Mediterranean World: Introduction to a neglected aspect of African diaspora, Slavery and Abolition, 13(1) 5-38,

Hunwick, J.O. (1995). Arabic Literature of Africa: The Writings of Central Sudanic Africa, Vol. 2. E.J.Brill.

Ibn Farid, M. S. (2021). An African Islamic Approach to Physics \& The Science of The Stars ('Ilm Tabaa'lyy Wa 'Ilm 'N-Nujuum) PART 1\& 2, online document accessed on $7^{\text {th }}$ January, also available: The Life \& Times of Shaykh Abd'I-Qaadir Dan Tafa: https://www.academia.edu/.../The_Life_of_Shaykh_Dan_Tafa...

Ibn Khaldun. (1978). The Muqaddimah: An Introduction to History, Franz, R (trans) N.J. Daward (ed) Great Britain.

Ibn Qayyim. (1994). The Prophetic Medicine, Abdu Anzar, S.Y. (trans)Beirut: Lebanon, p.3 Ismail, H.A. (1979). Medicine in 19th Century Arabic literature in Northern Nigeria: A Report, Postgraduate Seminar, History Department, Bayero University, Kano, Nigeria

Ismail, O.S.A. (1979). Some Reflections on the Literature of the Jihad and the Caliphate, in Y.B. Usman, (ed), Studies in the History of the Sokoto Caliphate, Longman: Nigeria.

Kani A. M. (1986). The Rise and Influence of Scholars in Hausaland before 1804, in Courier de'l Islam, 1985.

Kani, A.M. (1995). The Place of Katsina in the Intellectual History of Bilad al-Sudan up to 1800, Tsiga, I., and Adamu, A., (eds), Islam and History of Learning in Katsina.

Quick, A. H. (1995). Aspects of Islamic Social Intellectual History in Hausaland: Uthman Ibn Fudi, 1774-1804C.E. Ph. D. History, University of Toronto

Rose, C. (2003). Minerals, Metals, Faith and Slaves: The Trans-Saharan Commodity Trade, Hemisphere Summer Teachers Institute.

Usman, Y.B. (1983). A Reflection of the History of Relations between Borno and Hausaland before 1804, in Usman, B. and Alkali, N., (eds), Studies in the History of Pre-Colonial Borno, Zaria: NNPC. 
Zahraddeen, M. S. (1990). The Acquisition of land and its administration in the Sokoto Caliphate as provided by Abdullahi Danfodiyo's Ta'alim Al-Radi, in Kani, A. M., and Gandi, K. A.,eds, State and Society in the Sokoto Caliphate, Usmanu Danfodiyo University Press. 